\title{
Joseph Smith's plain and precious truths restored: A Christian apologetic response
}

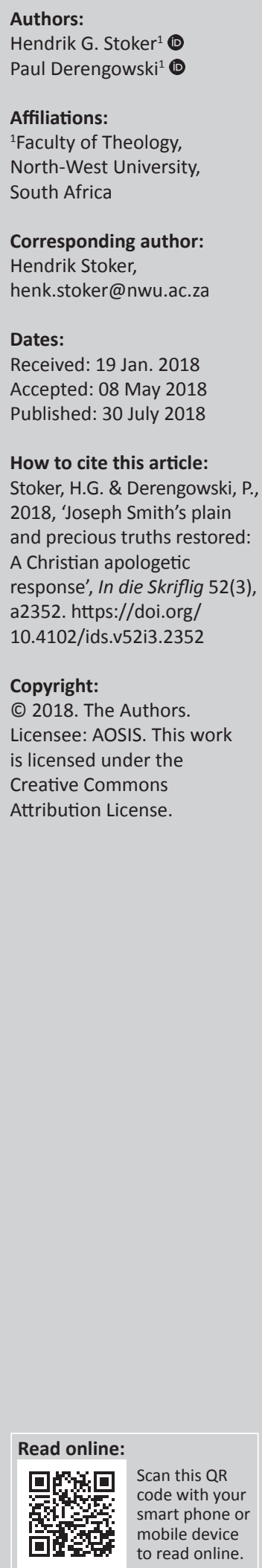

It has been the claim of Joseph Smith, the founder of Mormonism or the Church of Jesus Christ of Latter-day Saints that 'many plain and precious truths' have been removed from the Bible, although Smith did not explicitly or concisely elaborate on what those missing truths were. Later, Dr Clyde J. Williams of Mormon-owned Brigham Young University provided that concise list. Writing for Ensign magazine in October 2006, Williams argued for at least eight specific doctrines that were 'restored'. Upon examination and rebuttal, it is demonstrated that the Bible remains sufficient for all matters pertaining to Christian faith and practice, as John Calvin and the Reformers concluded years ago, and is emphasised in their stance on Sola Scriptura.

\section{Introduction}

Joseph Smith was the founder of Mormonism or The Church of Jesus Christ of Latter-day Saints. Of all the new religious movement leaders who started churches or organisations in 19th century America, Smith's has been the most prolific of them all. ${ }^{1}$ Neither Charles Taze Russell (International Bible Students to the Jehovah's Witnesses) nor Ellen G. White (Seventh Day Adventism) or Mary Baker Eddy (Christian Science) has equalled the influence that Smith and Mormonism have had upon America and many places abroad. Smith's influence included, among other things, an attack upon the Bible by claiming that it was deficient and erroneous. The writing of the Book of Mormon was alleged proof of the deficiency and error as it contained the 'plain and precious truths' that had been excised from the Bible, leaving it in a state of untrustworthiness, unless interpreted in light of the newly translated 'modern revelation'. The object of this article will respond to and rebut Smith's argument that 'many plain and precious truths' are missing from the Bible and demonstrate that his insertions, instead, are erroneous.

\section{The Bible and the Book of Mormon}

Joseph Smith claimed in 1 Nephi 13:26 and 28 that 'many plain and precious' truth had been removed from the Bible. The excision took place by authorisation from the 'great and abominable church' for the express purposes that, firstly, 'they might pervert the right ways of the Lord'; and secondly, 'that they might blind the eyes and harden the hearts of the children of men' (v. 27). Smith never provided a comprehensive list of exactly what those truths were that maliciously disappeared.

In October 2006, however, the Mormon Church published an article in its Ensign magazine that provided a concise explanation of Joseph Smith's presupposition. Ensign is the official publishing arm of the Mormon Church. Clyde J. Williams (2006) who is Professor of Ancient Scripture at Brigham Young University write the article entitled, 'Plain \& Precious Truths Restored'. It will serve as a basic outline for the response and rebuttal below.

Williams discussed eight important doctrines that he believes were removed from the Bible. They are the 'Premortal existence', 'Adam's fall and human suffering', 'Agency', 'The atonement', 'First principles and ordinances', 'Church organisation', 'Revelation', and 'Satan's

\footnotetext{
1.According the Mormon Newsroom, which is 'The Official Resource for News Media, Opinion Leaders and the Public', the Mormon Church, as of 2018, reports there are 15882417 members worldwide which includes 70946 missionaries and 159 temples in 189 Church, as of 2018, reports there a 15882417 members worldwide which includes 70946 missionaries and 159 temples in 189 countries (Facts and Statistics 2018). Ryan Cragun and Reuters estimate the net worth of LDS holdings at $\$ 35$ billion with an annual tithe and offering collection of $\$ 7$ billion annually (Henderson 2012). Elsewhere, the estimates are higher at $\$ 40$ billion and $\$ 8$ billion (see Fletcher Stack 2017) Although Seventh Day Adventist report more members, they are far less in annual tithes and offerings with the Jehovah's Witnesses and Christian Scientists even far less in membership and financial assets (see Annual Statistical Report 2017).
} 
identity and methods'. ${ }^{2}$ As the Book of Mormon serves as the standard by which Williams makes his case, a few comments will first be made about it before any commentary or rebuttal is made about the alleged missing 'plain and precious truths'.

\section{The Book of Mormon's alleged authority over the content of the Bible}

A sure-fire way for any Mormon to vindicate the claim that the Bible is missing many plain and precious truths is simply to provide the manuscript evidence. Instead of doing that, however, Williams and others regularly argue, 'A careful examination of the Book of Mormon reveals many significant insights not found in the Bible.' It is tantamount to saying, if a person will consult with the Operating Thetan III manual, written by L. Ron Hubbard of Scientology fame, that the existence of Xenu will be discovered. Xenu is not found in the Bible, because some nefarious Christian scribe must have removed it. Such logic, though, is impeccably flawed. Just because something does not appear in the Bible does not necessarily mean some evil person excised it from its pages. Rather, it was never a part of the Bible to begin with.

The fact of the matter is that despite all the effort expended by the Mormon Church and its hopeful apologists to corroborate the Book of Mormon storyline, it remains a work of verifiable controversy. Archeologically speaking, no one has ever found either the land or city of Zarahemla (Alma 2:26; Omni 1:12-13) or Bountiful (Alma 52:15, 17). No one has ever unearthed a vast Nephite city of cement houses (Helaman 3:7ff.). Modern-day Mormon apologists are even in conflict with Joseph Smith and the early Mormon leaders over the location of the Hill Cumorah that is a key site around which the Book of Mormon's story is told. ${ }^{3}$

Textually speaking, left unexplained are textual changes that have a direct bearing upon doctrinal beliefs. Is Mary the mother of God or the mother of the son of God (1 Nephi $11: 18,21,32)$ ? Will the Black man, upon converting to Mormonism, become 'white and delightsome' or merely 'pure and delightsome' (2 Nephi 30:6)? Are the Lamanites 'the principal ancestors of the American Indians' or are the Lamanites now only 'among the ancestors of the American Indians'? ${ }^{4}$ Added to all of these issues are the thousands of grammatical and spelling corrections done to the 'most correct of any book on earth' (Book of Mormon 2013 [1981]; Smith 1980 [1976]:4.461) and it becomes quite clear that the Book of Mormon fails as a credible document to be referenced to criticise biblical content.

2.These are the actual sub-headings in Williams' article

3.Joseph Fielding Smith (1954-1956:234) argued that, '.... the Prophet Joseph Smith himself is on record, definitely declaring the present hill [in upstate New York] called Cumorah to be the exact hill spoken of in the Book of Mormon' [Smith's emphasis]. Compare this with John L. Sorenson's guestimate (2013:142-143, 688, n82) of Cumorah's 'possible', yet 'tentative', location in Veracruz, Mexico as well as his biting condemnation that the hill in New York is 'manifestly absurd'.

4.See the revision between the 1981 'Introduction to the Book of Mormon' and the new and improved 2013 edition.

\section{Doctrines allegedly restored}

Premortal existence (see Ludlow 1992:3.1123; see also Smith 1978:29)

Citing Alma 12:25, Williams argues that the doctrine of 'Premortal existence' has been removed from the Bible. What he fails to do, though, is to inform the reader that Alma 12:25 mentions nothing about a premortal existence whereby Heavenly Father and Heavenly Mother are busy siring and conceiving spirit children on a celestial planet somewhere in the universe (see Anon 2009:11; 2017; Ballard 2016; Doctrine and Covenants [D\&C] 76:24; Hinckley 1997:256-257; Smith 1998:335; Marriott 2016; Moses 6:9), creating a family environment that all future Mormons hope to be a part of one day when they become gods and goddesses on their own planets as they sire and conceive their own 'premortal' spirit children (see Ballard 1966:211212; D\&C 132:22, 30-31; Ludlow 1978:1.2.131; McConkie 1966:231, 273, 321; 1973:3.204-205; 1979-1981:1.56-57, 215; 1982:264, 707; 1985:312; Smith 1976:300-301; Smith 1980 [1976]:5.391, Appendix A). In fact, Williams fails to mention that the concept premortal existence does not appear anywhere in the Book of Mormon; neither does 'spirit children', 'Heavenly Mother' or a 'heavenly family'. Alma 12:25 merely refers to the 'plan of redemption, which was laid from the foundation of the world' as well as the resurrection. Both redemption and resurrection are clearly discussed within the pages of the Bible (Mt 25:34; Eph 1:4ff. cf. Mt 22:30ff.; 1 Cor 15:1ff.).

Typically, the Mormons cite the prophet Jeremiah to support their argument for a premortal existence (see Adams 1992:2.721; Anon. 2008:67; 2015:13; 2016:7; Ash 2013:60; Brown 1992:3.1123; Cook 2012:35; Hinckley 2010:23; Hollowell 2010:69; Lee 1970:115; Ludlow 1962:18; Monson 2007:22-23; Nelson 2012:77; 2016:107; Nicholson 1899:770771; Nielsen \& Ricks 1992:1.342-343; Roberts 1905:894; Sill 1959:27; Talmage 1955:41). Several problems arise, however, when they do that. Firstly, the Book of Jeremiah is in the Bible and not the Book of Mormon. If such a 'significant insight' as the premortal existence has been removed from the Bible and is only found in the Book of Mormon, then referring to the Bible to find something that is missing or even implied as missing, is misleading or deceptive. If the doctrine is missing from the Bible, then the Mormons need to quit looking in the Bible to find it.

Secondly, the Mormon acceptance of Jeremiah 1:5 in the Mormon's own King James Version adaptation has no cross reference to the Book of Mormon that mentions anything about a premortal existence. At best, all a person will find are additional biblical references and more Mormon verbiage noting the 'Antemortal existence of Man'. A footnote at Isaiah 44:24 alluding to 1 Nephi 21:5 to support the premortal existence of human beings, is as misleading as the Alma 12:25 reference above. Again, if the doctrine is missing from the Bible, then there is no need to go looking for it there or to twist biblical references to find doctrinal inferences. 
Thirdly, the context of Jeremiah's comment has to do with Yawheh's omniscience and Jeremiah's future appointment not that there is any actual existence of Jeremiah in a family setting prior to his coming to earth to learn how to become a god. Moreover, if Jeremiah already existed, then in each instance where God 'formed' or 'planned' (יצָר) something or someone in the Old Testament, it could be argued that those

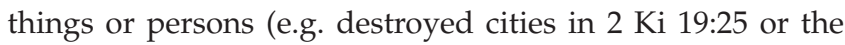
nation of Israel in Is 43:1) already existed prior to their coming to be. Reminiscences of Plato's Ideas and forms, which is clearly antithetical to the biblical worldview, immediately come to mind.

\section{Adam's fall and human suffering}

Williams presents a curious interpretation of the fall of man and human suffering in order to conclude that both of those subjects are missing from the Bible. He begins by writing, 'Many in the Christian world consider the Fall of Adam to be an accident or tragedy.' Is this not an admission that the fall of man is in the Bible and that biblical Christians look back on that event as the starting point of human suffering? If so, then this particular point invalidates the argument that at least one plain and precious truth is not missing from the Bible at all which further discredits his claims that the Book of Mormon contains something that the Bible does not contain. Also, Williams seems to imply that the fall of humanity was not tragic. His further commentary on the beneficial nature of the fall, as can be seen below, bears out such an assumption.

He alludes to 2 Nephi 2:22-25 to point out other missing truths that can only be realised by reading the Book of Mormon. The passage itself deals with Adam's beneficial fall. According to the reference:

[I]f Adam had not transgressed he would not have fallen, but he would have remained in the garden of Eden. And all things which were created must have remained in the same state in which they were after they were created; and they must have remained forever, and had no end..$^{23}$ And they would have had no children; wherefore they would have remained in a state of innocence, having no joy, for they knew no misery; doing no good, for they knew no $\sin . .{ }^{25}$ Adam fell that men might be; and men are, that they might have joy.

In other words, the Bible supposedly left out the following details:

- Sin was 'necessary' for Adam to escape the garden which was really a prison and not a paradise;

- Had Adam remained untainted by sin that would have been forever a bad thing, making sin a good thing;

- Adam could not obey God to be 'fruitful and multiply' until he disobeyed God;

- The state of innocence and obedience is also a state of guilt and disobedience;

- To live in misery is to live joyfully;

- Performing acts of goodness is contingent upon a person's knowledge of sin and then acting upon it;
- Human life is dependent upon Adam's death;

- Human purpose is to commit sin, because that results in joy, children, and eventually, godhood.

Added to these are several other important excisions that Williams mentions, including:

- Sin is a 'natural weakness ... designed to turn us to Christ', which makes lawlessness synonymous with lawfulness;

- 'Agency and opposition are essential to eternal growth' or godhood;

- Earthly human beings are currently enduring a 'state of probation' to see whether or not they will 'choose liberty and eternal life' as opposed to 'captivity and death'. The latter is orchestrated by the devil even though the devil originally advocated liberty and life for everyone, but was overruled by God who chose Jesus' plan, which was really God's plan all along, that wanted liberty and life only for some. ${ }^{5}$

A full-blown rebuttal is impossible here. Nevertheless, to assert that sin is 'necessary' for 'God's plan' is an equation fraught with logical impossibilities and endless conundrums after the order of Jesus' statement that a 'house divided against itself cannot stand' (Mt 12:25). Sin, in other words, is not necessary, but contingent - much like a parasite relying on its host for survival. Adam no more needed to be disobedient toward God in order to obey God than he needed to commit an act of sin in order to be joyous. Sin always results in death and separation ( $\operatorname{Rm} 5: 12 ; 6: 16,23 ; 8: 13)$ which is the message that God delivered to Adam when God commanded him to refrain from eating the fruit from the tree of the knowledge of good and evil (Gn 2:17). To die, you shall surely die, ${ }^{6}$ was the warning; not, rebelling against God's command will bring an enjoyable brood of children. The Mormon idea that the fall was removed from the Bible cannot stand, because it contradicts everything the Bible has to say about God: creation, humanity, sin and redemption.

\section{Agency}

According to Williams, 'The principle of man's right to act according to his own will or desires is a major theme throughout the Book of Mormon.' Whether eight Book of Mormon references constitute 'throughout' or not, is a matter of opinion. . What is certain is that agency or 'Free Agency', as it is sometimes termed, is important to Mormons. ${ }^{8}$ It is so important that Mormonism's founder, Joseph Smith Jr.,

5.This story, which is basic to Mormon theology, is ironically not found in the Book of Mormon. It is found in the Book of Moses 4:1 and further, or Pearl of great price where the dubious Book of Abraham is also found.

6.At Genesis 2:17 we read, '... the day that you eat from it [the tree of the knowledge of good and evil] you will surely die'. Literally, the phrase 'to die, you will die!' $ת$ ing is a qal infinitive absolute which, when combined with the qal imperfect verb תמฺָָּ, it emphasises or magnifies the result.

7.He cited Mosiah 2:21; Alma 29:4-5; 41:3, 5; 42:27; Helaman 3:28-29; 7:5; 12:3-6; and $14: 30-31$ as evidence.

8.From January 2001 to April 2017, the main magazine, Ensign, published by The Church of Jesus Christ of Latter-day Saints, shows 1263 occurrences in 178 publications where the word 'agency' has either been used or discussed in its teaching articles. In other words, $91 \%$ of the magazines since the turn of the new teaching articles. In other words, $91 \%$ of the magazines since the turn of the new
millennia therefore have reserved space to discuss this one 'major theme' of the Mormon faith. 
(1980 [1976]:2.7), labelled agency as one of the human family's 'choicest gifts'. Brigham Young (Widtsoe 1978:62) called agency a 'right' that 'God has given to all people who dwell on the earth, and they can legislate and act as they please', with the caveat that God still legislates the results. Lorenzo Snow (Williams 1996:4) argued 'Free agency is needed for godhood', as 'the principle of God', meaning his 'nature and character', resides 'in every individual'. Joseph Fielding Smith (1952:15), like Lorenzo Snow claimed, 'There could be no progression, no real existence, without this great gift ... It is an eternal principle.' According to Bruce R. McConkie (1985):

All of the terms and conditions of the Lord's eternal plan operate because man has his agency, and none of it would have efficacy, virtue, or force if there were no agency. (p. 89)

Gordon B. Hinckley (1997:55) wrote, 'Man is free to choose his own way. There is no predestination in Mormon theology. Free agency is a sacred gift, divinely bestowed.'

Williams, Joseph Smith and the rest of the Mormon faithful are correct in concluding that the concept of Agency, free agency, or even free will is found nowhere in the Bible. That does not necessarily mean that some wily scribe(s) removed it. What it means is that, because of the biblical description of sin and its consequences upon the world, the freedom to think and act apart from its influence has been forfeited. The thoughts and intents of man's heart are 'only evil continually' (Gn 6:5 cf. 8:21; Eccl 9:3; Jr 17:9; Mk 7:21-23; Jn 3:19; Rm 8:6-8; 1 Cor 2:14; Eph 4:17-19;5:8). Hence, men and women are not free, but are slaves to $\sin$ (Jn 8:34; Rm 6:6, 16-20). Freedom only occurs when Christ sets the sinner free, which comes only through the born again experience associated with spiritual regeneration (G1 5:1; Jn 3:3,5). Until such time, the sinner only thinks and acts according to his nature, which is bound, not free. A byproduct of such bondage is the creation of one's own selfrighteous religiosity, whereby sinners attempt to cover themselves with the works of their own hands (Gn 3:7), then run and hide from God (Gn 3:8 cf. Ps 10:4; 119:155; Rm 3:11, 18).

Given the distorted view of the fall by the Mormons, as seen above, whereby sin is interpreted as a fall upwards toward godhood, it should come as no surprise that they also believe that they now have the right to tell God what they are going to do, whether in matters of morality or eternality. God is at the mercy of the sinner, not the sinner at the mercy of God. To argue for the biblical view of sin and what it does to place human beings in bondage, is to be in league with Satan. This fails to account for the biblical fact that it was, in the first place, Satan who tempted Eve to exercise her 'free agency' against God (Gn 3:1-5). If Satan wanted to strip humanity of its free agency and save everyone without compulsion, then why encourage Adam and Eve to act freely in a way that would bind them in sin, while presuming they were still free to accept or reject God's plan of salvation later? It is a convoluted conundrum of Pelagian propensity. ${ }^{9}$

9 Pelagius was a 5 th century British monk who misunderstood the fall of man as well as the role of God's grace. To him the fall did not corrupt man to the extent that the Bible portrays humankind afterward. Hence, original sin was denied and God's grace Bible portrays humankind afterward. Hence, original sin was denied and God's grace was reinterpreted as an abiding power to enable man to still know and choose
between good and evil as man's will dictated (see Harold O.J. Brown 1988:202).

\section{The atonement}

The fourth 'plain and precious truth' allegedly missing from the Bible, according to Williams, involves the atonement. However, Williams fails to discuss the atonement itself. He does not address the 93 references to the atonement that are found in the Old Testament or the additional 104 references stemming from the Hebrew root כפר, which broadly means 'to cover'. Moreover, aside from a passing parenthetical referral to Romans 5:11, Williams says nothing about Jesus Christ's death on the cross to reconcile (2 Cor 5:18-20; Eph 2:16; Col 1:20, 22), propitiate ( $\operatorname{Rm~3:25;~Heb~2:17;~} 1$ Jn 2:2; 4:10), or redeem (Gl 3:13; Tt 2:14; $1 \mathrm{Pt}$ 1:18) the sinner unto God. Instead, Williams has redefined the atonement to include Jesus' salvific mission beginning in the Old Testament, ${ }^{10}$ the necessity of the English word atonement to appear a number of times in a sacred text to sufficiently account for its importance, and above all, the inclusion of 'the obedient efforts of mankind' to 'merit' God's grace as prerequisite before anyone is saved (see Smith 1980 [1976]:2.27).

The atonement, in other words, is not missing from the Bible and thereby Williams' premise is negated. What are missing from the Bible are anachronistic allusions to Jesus. Jesus did not show up in Old Testament times, because it was not his time to fulfil God's plan of redemption on the cross (Mt 26:18; Jn $2: 4 ; 7: 6,30)$. What are missing from the Bible are specific English translations of certain words to appease Mormon presuppositions. Other words have been used, as seen above; some of which are the same, especially in the Old Testament, even though they are understood differently than what the Mormon might expect to qualify those presuppositions. What are missing from the Bible are the efforts of fallen humanity to be able to garner from God his grace whereby, if the human being so chooses, he or she can save him- or herself. ${ }^{11}$ It is missing, because salvation is from God and by God, and until God graciously moves to redeem the sinner, the sinner is 'dead in trespasses and sins' (Eph 2:1-2),

10.Williams defers to Jeffrey Holland's conflicted comment found in his book Christ and the New Covenant (1997:6-7). Speaking of The Atonement in a separate chapter, Holland wrote:

Our [natural and unregenerate] hearts can - and in their purity, do - desire that which is spiritual and holy rather than that which is 'carnal, sensual, and devilish'. If that were not so, we would be in a hopeless condition indeed, and the idea of real choice would be jeopardized forever. (p. 207)

It is incredible that someone could, on the one hand, be so absolutely right, while denying its truthfulness with something that is so absolutely wrong. The Apostle Paul made it clear that human beings, in their unregenerate condition, have zero desire for God, do not do what is right in God's estimation, nor do they fear God Rm. 3:10ff.). Because human beings are 'lost' in bondage to sin and totally incapable of rescuing themselves, they are hopeless, in jeopardy of eternal damnation and without God in the world. Holland, though, like Williams, impose his Pelagian-like interpretation upon the Atonement of Christ in an effort to mitigate the natural man's dire condition. The unregenerate human is 'naturally miti', not just 'inherently evil' (Holland 1997:206), which are why he or she is evil', not just 'inherently evil' (Holland 1997:206), which are why he or she is capable in and of him- or herself of changing his or her condemned stance befor God by simply acting on his or her natural purity. As Jesus did his part to bring redemption through the atonement, now all human beings have to do is their part what the a is onward to exaltation and, godho is such unabashed distortion of what the atonement is really all about, which is the covering of $\sin$ through the blood of Christ, will only leave those Mormons who accept its twisted explanation accursed and on the road to the devil's hell.

11.Joseph Smith (1980 [1976]) addressing the subject of the resurrection by saying the following:

I am going on in my progress for eternal life. It is not only necessary that you should be baptized for your dead, but you will have to go through all the ordinances for them, the same as you have gone through to save yourselves. ordinances for them, the same as you have gone through to save yourselves.
There will be 144,000 saviors on Mount Zion, and with them an innumerable host that no man can number. (p. 6.365) 
incapable of impressing or wooing God through the sinner's own boastful and self-righteous acts (Eph 2:8-9). It is missing, because, if salvation can be merited, then Jesus died in vain (Gl 2:21). It is missing, because, if salvation is a cooperative effort of human works and God's grace, and not according to God's grace exclusively, then grace is no longer grace (Rm 11:6). Clearly, the atonement, along with all of its intertwined doctrines, is not missing from the Bible. What are missing are all the presupposed, twisted, Mormon interpretations about the atonement.

\section{First principles and ordinances}

In defence of the presupposition that the Bible is 'missing many plain and precious truths' regarding first principles and ordinances, Williams (2006) wrote:

The Old Testament does not clearly teach the principles of faith, repentance, baptism, and the gift of the Holy Ghost, and their interrelationship, but Book of Mormon prophets Nephi, Jacob, Alma, and his son Alma all taught the importance of these principles prior to the coming of Christ. (p. 53)

It should be noted that Williams changes his argument from 'many significant doctrines not found in the Bible' to focus on what he perceives is the inadequacy of the Old Testament. Such a change, however, only serves to defeat what he originally set out to prove which is the deficiency of the whole Bible and not just one portion of it. Clearly, faith, repentance, baptism and the gifts of the Spirit are all taught in the Bible, although not equally nor necessarily depending on the context and the timeliness of the revelation. While the Old Testament does not mention baptism or the gifts of the Spirit that in no way signifies that those important 'principles' are missing from the Bible. Circumcision in the Old Testament served as the identifying 'principle' for the Israelites just like baptism later serves as the identifying 'principle' for New Testament Christians. While the Old Testament believer may not necessarily have been gifted in the same sense as the New Testament believer, the Spirit of God still filled the Old Testament believer with his temporary presence and enabled him or her to act or think wisely (Dt 34:9; Ex 31:3; 35:31; Ezk 43:5; Mi 3:8). Therefore, between changing the structure of his argument and failing to consider the whole of the Bible when discussing his specificities, this particular premise of Williams fails to support his overall argument.

\section{Church organisation}

Williams' next premise deals with church administration which, he claims, is the basis for what is found in $D \& C$, section 20, and something that is not found in the Bible. In D\&C 20 there is the high praise of the Book of Mormon (vv. 1-16), commentary on the fall of humanity, the crucifixion, salvific requirements, and the Mormon Trinity (vv. 17-29), more praise for the Book of Mormon (vv. 30-36), a verse dealing with baptismal procedure (v. 37), clarification of church officers and their responsibilities (vv. 38-67), the responsibilities of church members (vv. 68-74), scripted prayers, church discipline, and church expulsion procedures (vv. 75-84). With the exception of praise for the Book of Mormon and scripted prayers, all of the remaining doctrines and beliefs are found in the Bible.

The Fall of Man is found in Genesis 3. The crucifixion of Jesus is found in Matthew 27, Mark 15, Luke 23 and John 19. The salvific requirements are found in John 3, Romans 10, Ephesians 2 and elsewhere. An allusion to the biblical Trinity is seen in Genesis 1:26-27, Judges 13:21-24 and Psalms 33:69, and is more explicitly found in Jesus' baptism (Mt 3:16-17; Mk 1:9-11; Lk 3:21-22), Jesus' warning (Mt 12:28-32) and Jesus' command (Mt 28:18-20). The Apostle Paul closed his second letter to the Corinthians with, 'The grace of the Lord Jesus Christ, the love of God, and the fellowship of the Holy Spirit, be with you all' (13:14). In fact, with the exceptions of the Book of James, and 2 and 3 John, the Trinity is referred to in one way or another throughout the New Testament. Baptism is found 90 times in the New Testament, starting with John the Baptist's ministry and finishing with Peter's comment that 'baptism now saves you - not the removal of dirt from the flesh, but an appeal to God for a good conscience - through the resurrection of Jesus Christ' (1 Pt 3:21). Church polity and governance is seen in the calling of Jesus' disciples (Mt 4:18-22; Mk 1:16-20), but more specifically in the early chapters of the Book of Acts, and Paul's letters to Timothy and Titus. The responsibilities and behaviour of church members can be found throughout the New Testament, culminating in the command to 'love one another' (Jn 13:34; Rm 13:8; 1 Th 4:9; 1 Pt 1:22; 1 Jn 3:11, 23; 4:7, 11-12; 2 Jn 5). The subject of church discipline is found in Matthew 18:15 and further, and expulsion of church members in 1 Corinthians 5:1 and further. With so much found in the Bible regarding these subjects, it is hard to fathom that anyone would claim they are missing.

\section{Revelation}

In defence of this particular point, Williams wrote: 'The Book of Mormon demonstrates and teaches the importance of personal revelation for all.' The Encyclopedia of Mormonism (Ludlow 1992:3.1225) listed 11 instances that constitute 'personal revelation', ranging from theophanies to angelic visitations to 'manifestations of the light of christ, by which all men know good from evil'. Interestingly, unless such revelation is received by the President of Mormonism, according to Stephen Robinson (1991:17), 'the Lord commands them to keep it to themselves (see Alma 12:9)'. Williams continued, 'From beginning to end it is the classic example that the heavens are still open and that God does indeed speak to men on earth.' What is curious is that if the heavens are open and God is still speaking to men on earth, then why cannot such 'personal revelation' be openly shared and accepted by everyone? Why is there a need for ecclesiastical sanction, if indeed the revelation is from God? Finally, Williams lauds, 'The Book of Mormon also reveals the role and ministry of angels in detail not found in the Bible (see Moroni 7:29-32)'. Of course, at least one angel, either Nephi or Moroni, plays an especially large role in Mormon 
Church development. ${ }^{12}$ A question that could be asked is what happened to him? Why does he no longer play an equally important role in Mormon revelation? Surely, if revelation is a continuing occurrence and angelic ministry is such a large part of it, then where is Nephi or Moroni today given his importance in early Mormon history and doctrine? ${ }^{13}$

The Bible makes it perfectly clear that humanity has not been left without any contemporary communication with God. When Jesus promised the coming of the Paraclete or Holy Spirit, he said that the Spirit would not only abide in each Christian (Jn 14:17), but that he would 'bring to your remembrance all that I said to you' (Jn 14:26). Such words of remembrance have been recorded in the New Testament. Given the textual critical effort of many to ensure the integrity of the text, the objective observer will have to admit Jesus' words are still found recorded there. Moreover, when the Spirit comes:

He will guide you into all the truth; for He will not speak on His own initiative, but whatever He hears, He will speak; and He will disclose to you what is to come. (Jn 16:13)

In other words, a combination of internal witness with external written testimony constitutes the divine communication of God that he wishes all Christians to understand and then put into practice. It is not something 'new' or outlandish that has nothing to do with Jesus (such as the discovery of the Reformed Egyptian Jewish American Indians), but a focused witness upon Jesus so that the followers of Jesus would be more like him.

Discussion about angels, their mission for God and ministry toward men is also extensive throughout the Bible. They were around when God created the heavens and the earth (Job 38:7). They assisted one of God's own, namely Lot when God destroyed Sodom and Gomorrah (Gn 19:1ff.) and they will be around helping God to carry out the final destruction of wicked humanity, Satan and his minions, and the created order itself at the end of time (Rv 7:1-12:9; 14:17-20:1). God's angelic realm will be more noticeably active toward the end of the age than at any time during human existence. ${ }^{14}$ In the meantime, Hebrews 1:14 tells us that angels are 'ministering spirits, sent out to render service for the sake of those who will inherit salvation' which is consistent with Peter's observation that angels were interested in the gospel message preached by the prophets (1 Pt 1:12). In fact, at the end of the age an angel will be seen preaching the gospel to everyone who lives on the earth, regardless of nation, tongue, tribe or people (Rv 14:6). There is therefore no reason to believe that they are currently inactive, although a caveat has been given

\footnotetext{
12.According to W. Woodruff (1842), the name of the angel was Nephi. Later, the
} angel is identified as Moroni.

13.According to Joseph Smith (1980 [1976]:1.18-19), when he 'had accomplished by [the plates] what was required at [his] hands', the angel Moroni 'called for them'. Joseph then 'delivered them up to him; and he has them in his charge until this day, being the second day of May, one thousand eight hundred and thirty-eight'. There is no record of him returning to deliver any other revelations once he took the gold plates back into his possession. No explanation was given why he took them either.

14.Of the 290 references to the English translation of angel, found in the New American Standard Bible, 73 of them are found in the Book of Revelation which is three times that found in the next highest occurrence found in the Gospel of Luke. to respect certain angels whose sole intent is to pervert the gospel. ${ }^{15}$ Space precludes a fuller discussion of both good and bad angels. The Bible, however, is quite adequate to describe their activities - both now and in the future - negating any claim that they are somehow 'missing'.

\section{Satan's identity and methods}

Williams' last point fails from the outset, because he claims that, 'The knowledge of Satan and his influence is virtually absent from the Old Testament' [author's emphasis]. That is different from his original argument, which claims that many plain and precious truths had been 'taken away' from the Bible or that 'many significant doctrines are not found in the Bible'. If such truths were taken away or can no longer be found in the Bible, they are not 'virtually absent'. They are completely absent. Nevertheless, after citing two Christian resources, he resorts to the Book of Mormon as proof that what it has to say about Satan is missing from the Bible. ${ }^{16}$ The fallacy here is simply begging the question. It assumes what Williams sets out to prove. Because Williams presupposes that, in the first place, the Book of Mormon is the great corrector of the Bible, and in the second place, the Bible is flawed, then the only way to fill in the gaps and correct the errors is by accepting his first premise that just happens to be also his conclusion. When that occurs, it also affirms that there are all of these plain and precious truths that have been restored and thereby reaffirming the integrity of the Book of Mormon and calling into question the Bible all over again. Descartes would have been proud of this argumentation. ${ }^{17}$

Allusions to Satan and to his methods are quite clear in the Bible, though. Not only are there specific references to him throughout scripture - and more particularly in the New Testament - in the first book of the Bible, Genesis, his tactic is laid out and has been successfully repeated and employed ever since. Satan, who is later identified as 'the great dragon ... the serpent of old who is called the devil' ( $R v$ 12:9), approached Eve in the Garden of Eden first with a question, 'has God said' and then a rebuttal. The question dealt with

15.See Galatians $1: 8$ and 2 Corinthians $11: 14-15$ as examples.

16.The first of his sources, an article written by Theodor H. Gaster in The Interpreter's Dictionary of the Bible is conflicted (if not simply incorrect) by his second source, Leon Morris' article on 'Satan' in the New Bible Dictionary. Gaster (Buttrick 1962:4.224) claims that, 'Nowhere in the OT does Satan appear as a distinctive demonic figure' and then goes on to cite three references in the Old Testament (Job 1-2, Zech 3:1-2, and 1 Chr 21:1) where the appellative הַשָׁ refers to a distinctive 'superhuman being', but its name is not 'Satan'. Using some rather tenuous grammatical reasoning, Gaster assumes that, because of the attending definite article $\pi$, somehow negates Satan's identity. Therefore, the name definite article $\pi$, somehow negates Satan's identity. Therefore, the name
could apply to anyone, perhaps even Satan himself, although no one knows for could apply to anyone, perhaps even Satan himself, although no one knows for
certain. Not only does such conflict with basic Hebrew grammar and usage of the certain. Not only does such conflict with basic Hebrew grammar and usage of the
definite article (see Chisholm 1998:37; Ross 2001:59), it conflicts with Morris who

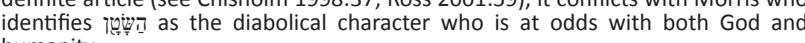
humanity.

The latter conflict also reveals that Williams misrepresented Morris as a source by cutting off his statement in mid-course. While Morris (Douglas 1982) did write, 'Admittedly we have not yet the fully developed doctrine', however, he continued:

but the activities of 'the Satan' are certainly inimical to Job. The OT references to Satan are few, but he is consistently engaged in activities against the best interests of men. (p. 1074)

Morris then goes on to cite examples where he hampers David and Joshua, and then concurs with John's statement in 1 John 3:8 about the devil sinning from the beginning by asserting 'the OT references to him bear this out'.

17.Decartes (Copleston 1946-1974:4.90-93) is the philosopher who is famous for his dictum, 'I think, therefore I am'. But, as Kreeft (2005:94) pointed out, despite its fame, such a statement is actually the logical fallacy of 'Begging the Question' or 'Arguing in a Circle' (pp. 95-96) 
God's word - much like Williams, the Mormons and all others who doubt it. It is not only a question of veracity and integrity, but authority. Satan wanted Eve not only to question her own recollection, but also to question whether or not God could order something contrary to her own rationale. He wanted her to doubt God and then act independently to fill in the blanks. As soon as she doubted and responded in disobedience, the rebuttal followed that led to her temptation and ultimate fall. It is a devious tactic that Satan has used with great success ever since and it begins by asking, 'Has God said?' Therefore, this premise fails, as all of the other premises Williams has presented thus far.

\section{Conclusion}

Williams wraps up his article by informing the reader that, 'We have just scratched the surface. The number of plain and precious truths restored is voluminous.' While those opinions might be a comforting thought to some, based on what he has already presented in this article, they are fleeting. In each example, whether touting the Book of Mormon's authority or the supposed plain and precious truths missing, what is to be argued has nothing to do with real, actual tangible articles of faith and doctrine that have been removed by some unnamed malicious individual or individuals. It has to do with presuppositions projected onto both the Bible and Christianity. Several passing comments, alluding to Plato, Pelagius and Descartes, all serve as kinds of philosophical worldviews that influenced Joseph Smith when he set out to 'restore' what he thought were ancient Christianity. Those worldviews, along with several others not mentioned here, continue to be repeated by persons like Clyde Williams in the Mormon effort to persuade the naïve and unwary that Mormonism is another denomination of Christianity - if not Christianity itself.

Earlier, a question about motives was raised and at the end of Williams' article, he provided what appears to be the key motive behind the whole plain and precious truths theme: human attainment unto godhood. Williams (2006:54) wrote that Joseph Smith 'was the instrument God used to reveal many lost truths and once again "make plain the old paths" that, if followed, will lead one to exaltation and eternal life'.

Exaltation and eternal life, however, have special connotations in Mormonism that are unrelated to anything a person might find elsewhere. Eternal life means life as a god, for, as Bruce McConkie (1966) explained:

The word eternal, as used in the name eternal life, is a noun and not an adjective. It is one of the formal names of Deity (Moses 1:3; 7:35; D. \& C. 19:11) ... God's life is eternal life; eternal life is God's life - the expressions are synonymous. (p. 237)

Those who gain eternal life, gain life as God's or 'receive exaltation ... They are gods'. McConkie (1966:257) repeats the same explanation when discussing separately the subject of Exaltation. The ultimate motive for Williams, McConkie and others for discrediting the Bible as missing many plain and precious truths and exalting the Book of Mormon or any other extra-biblical source of authority, for that matter, is to emphasise the serpentine promise of godhood first offered to Eve if she would simply ask herself, 'Has God said?' (Gn 3:5). The only difference is that Williams, McConkie and the rest of the Mormon faithful, choose to use their own Mormon specific language to express the same goal. Ironically, even that goal is found in the Bible, regardless of its diabolical falsity and thereby, once again, falsifying the whole idea that something plain and precious is missing from the Bible.

\section{Acknowledgements}

The authors would like to thank the North-West University for their support.

\section{Competing interests}

The authors declare that they have no financial or personal relationships which may have inappropriately influenced them in writing this article.

\section{Authors' contributions}

S.P.D. did the research for this article as part of his $\mathrm{PhD}$ studies, under the supervision of H.G.S. who is his $\mathrm{PhD}$ promoter.

\section{References}

Adams, W.J., Jr., 1992, 'Jeremiah, prophecies of', in D.H. Ludlow (ed.), Encyclopedia of Mormonism, vol. 2, pp. 721-722, Macmillan, New York.

Annual Statistical Report, 2017, 153rd Report of the General Conference of Seventhday Adventists ${ }^{\circledR}$ for 2015 and 2016, viewed 4 December 2017, from http:// documents.adventistarchives.org/Statistics/ASR/ASR2017.pdf

Anon., 2008, 'The gospel of Jesus Christ teaches the reality of our premortal existence,' Ensign 38(6), 67

Anon, 2009, Gospel Principles, Salt Lake City, UT.

Anon., 2015, 'Our premortal life,' New Era 45(2), 13.

Anon., 2016, 'Daughters of our eternal father,' Ensign 46(4), 7.

Anon., 2017, 'Why don't we know much about our Heavenly Mother?', New Era 47(3), 41. Ash, M.R., 2013, 'The restoration and early Christian teachings,' Ensign 43(4), 60-65. Ballard, M.J., 1966, Crusader for righteousness, Bookcraft, Salt Lake City, UT. Ballard, R.M., 2016, 'By study and by faith', Ensign 46(12), 22-29.

Book of Mormon, 2013 [1981], Introduction, The Church of Jesus Christ of Latter-day Saints, Salt Lake City, UT.

Brown, G.O., 1992, 'Premoral life', in D.H. Ludlow (ed.), Encyclopedia of Mormonism, vol. 3, pp. 1123-1125, Macmillan, New York.

Brown, H.O.J., 1988, Heresies, Hendrickson, Peabody, MA.

Buttrick, G.A. (ed.), 1962, The interpreter's dictionary of the Bible, Abingdon, New York. Chisholm, R.B., Jr., 1998, From exegesis to exposition, Baker, Grand Rapids, MI.

Cook, Q.L., 2012, 'The doctrine of the father,' Ensign 42(2), 33-36.

Copleston, F., 1946-1974, A history of philosophy, 9 vols., Image Books, Garden City, NY. Douglas, J.D. (ed.), 1982, New Bible dictionary, InterVarsity, Leicester.

Facts and Statistics, 2018, 'Growth of the church', viewed 12 April 2018, from https:// www.mormonnewsroom.org/facts-and-statistics

Fletcher Stack, P. 2017, 'Historian digs into the hidden world of Mormon finances, shows how church went from losing money to making money - lots of it', viewed 12 April 2018, from https://www.sltrib.com/religion/local/2017/10/14/historiandigs-into-the-hidden-world-of-mormon-finances-shows-how-church-went-fromdigs-into-the-hidden-world-of-mormon-fin
losing-money-to-making-money-lots-of-it/

Henderson, P., 2012, 'Insight: Mormon Church made wealthy by donations', viewed 12 April 2018, from https://www.reuters.com/article/us-usa-politics-mormons/ insight-mormon-church-made-wealthy-by-donations-idUSBRE87B05W20120812 Hinckley, G.B., 1997, Teachings of Gordon B. Hinckley, Deseret, Salt Lake City, UT. Hinckley, G.B., 2010, 'Why these temples?', Ensign 40(10), 21-27.

Holland, J.R., 1997, Christ and the new covenant, Deseret, Salt Lake City, UT. 
Hollowell, B., 2010, 'Where did I come from?', Ensign 40(7), 69.

Kreeft, P., 2005, Socratic logic, 2nd edn., St. Augustine's Press, South Bend, IN.

Lee, H.B., 1970, 'President Harold B. Lee,' in General Conference Reports, pp. 113-118, The Church of Jesus Christ of Latter-day Saints, Salt Lake City.

Ludlow, D.H., 1962, 'Man's pre-earthly existence,' The Improvement Era 65(1), 17-19. Ludlow, D.H., 1978, A companion to your study of the doctrine and covenants, 2 vols. Deseret, Salt Lake City, UT. (Infobase Library CD-ROM).

Ludlow, D.H. (ed.), 1992, Encyclopedia of Mormonism, 4 vols., Macmillan, NY.

Marriott, N.F., 2016, 'What shall we do?', Ensign 46(5), 10-12.

McConkie, B.R., 1966, Mormon doctrine, Bookcraft, Salt Lake City, UT.

McConkie, B.R., 1973, Doctrinal new testament commentary, Bookcraft, Salt Lake City, UT. McConkie, B.R., 1979-1981, The mortal messiah, Deseret, Salt Lake City, UT.

McConkie, B.R., 1982, The millennial messiah, Deseret, Salt Lake City, UT.

McConkie, B.R., 1985, A new witness for the articles of faith, Deseret, Salt Lake City, UT.

Monson, T.S., 2007, 'Mrs. Patton - the story continues,' Ensign 37(11), 21-24.

Nielsen, F.K. \& Ricks, S.D., 1992, 'Creation, creation accounts', in D.H. Ludlow (ed.), Encyclopedia of Mormonism, vol. 1, pp. 340-343, Macmillan, New York.

Nelson, R.M., 2012, 'Thanks be to God,' Ensign 42(5), 77-80.

Nelson, R.M., 2016, 'Decisions for eternity,' Ensign 42(11), 106-109.

Nicholson, J., 1899, 'Origin and nature of man, from the standpoint of revelation and reason,' The Improvement Era 2(10), 767-774.
Roberts, B.H., 1905, 'The fall of Adam - the purpose of man's existence,' The Improvement Era 8(12), 881-902.

Robinson, S.E., 1991, Are Mormons Christians?, Bookcraft, Salt Lake City, UT.

Ross, A.P., 2001, Introducing biblical Hebrew, Baker, Grand Rapids, MI.

Sill, S.W., 1959, 'Here I am ... send me,' The Improvement Era 62(1), 27-28.

Smith, J., 1976 [1980], History of the church, 8 vols., Deseret, Salt Lake City, UT.

Smith, J.F., 1952, The progress of man, The Genealogical Society of Utah, Salt Lake City, UT.

Smith, J.F., 1954-1956, Doctrines of salvation, 3 vols., Bookcraft, Salt Lake City, UT.

Smith, J.F. 1976, Teachings of the Prophet Joseph Smith, Deseret, Salt Lake City, UT.

Smith, J.F., 1978, The way to perfection, Deseret, Salt Lake City, U.T

Smith, J.F., 1998, Teachings of presidents of the church: The Church of Jesus Christ of Latter-day Saints, Salt Lake City, UT.

Sorenson, J.L., 2013, Mormon's codex, Deseret, Salt Lake City, UT.

Talmage, S.B., 1955, 'Value beyond price,' The Improvement Era 58(1), 19, 41-42.

Widtsoe, J.A. (compiler), 1978, Discourses of Brigham Young, 1978, Deseret, Salt Lake City, UT.

Williams, C.J. (ed.), 1996, The teachings of Lorenzo Snow, Bookcraft, Salt Lake City, UT.

Williams, C.J., 2006, 'Plain \& precious truths restored', Ensign 26(10), 50-54.

Woodruff, W., 1842, 'History of Joseph Smith', Times and Seasons, 15 April, p. 753. 